\title{
Perniagaan Online Syariah: Suatu Kajian dalam Perspektif Hukum Perikatan Islam
}

\author{
Suhartono \\ Pengadilan Agama Kabupaten Gresik Jawa Timur \\ suhartono_71@yahoo.com
}

\begin{abstract}
:
Along the vast development in information technology, it creates a new variant in business relation, that once was primarily physical with papers as the transaction mechanism tools, shifts into a more virtual relationship pattern using digital media or well known as electronic commerce (ecommerce).

There has been a transformation in the jurisdictional review towards agreement forms, from the conventional trading using textual document with "tinta basah" and physical contact in a real space, into a digital model where all the documents are made in a cyber space.

This transaction model provides several benefits within its operational, nevertheless its presence also emerges new complex legal problems regarding the legality of a contract or an agreement, especially in the Islamic law perspective. Does an Islamic bonding law also accommodate this ecommerce transaction model?
\end{abstract}

Keywords: e-commerce, online contract, online business.

\section{Pendahuluan}

Beragam pendapat dikemukakan oleh para pakar teknologi informasi dan praktisi bisnis dalam mendefinisikan perniagaan online (ecommerce). David Baum mendefinisikan "E-commerce is a dynamic set of technologies, applications, and business process that link enerprises, consumers, and communities through electronic tansactions and the electronic exchange of goods, services, and information". E-commerce merupakan satu set dinamis teknologi, aplikasi dan proses bisnis yang 
menghubungkan perusahaan, konsumen dan komunitas tertentu melalui transaksi elektronik dan perdagangan barang, jasa dan informasi yang dilakukan secara elektronik. Sementara Amir Hartman mendefinisikan ecommerce sebagai suatu jenis dari mekanisme bisnis secara elektronik yang memfokuskan diri pada transaksi bisnis berbasis individu dengan menggunakan internet sebagai media pertukaran barang atau jasa baik antara dua institusi (business to business) maupun antarinstitusi dan konsumen langsung (business to consumer) (Asnawi, 2004:15).

Lebih lanjut, berdasarkan United Nations Commission on International Trade Law (UNCITRAL), Model Law on Electronic Commerce with Guide to Enactment dinyatakan sebagai berikut:

"The term 'commercial' should be given a wide interpretation so as to cover matters arising from all relationship of a commercial nature whether contractual or not. Relationships of a commercial nature include, but are not to, the following transactions: any trade transaction for the supply or exchange of goods or services; distribution agreement; commercial representation or agency; factoring; leasing; construction of works; consulting; engineering; licensing; investment; financing; banking; insurance; exploitation agreement or concession; join venture and other forms of industrial or business cooperation; carriage of goods or passengers by air, sea, rail or road."

Berdasarkan ruang lingkupnya, maka dapat diurutkan sebagai berikut (Makarim, 1999: 2):

1. Electronic Business adalah untuk lingkup aktivitas perdagangan dalam arti luas.

2. Electronic Commerce adalah untuk lingkup perdagangan/perniagaan yang dilakukan secara elektronik, termasuk:

- Perdagangan via internet (internet commerce);

- Perdagangan dengan fasilitas web internet (web commerce), dan

- Perdagangan dengan Sistem Pertukaran Data Terstruktur secara Elektronik (Electronic Data Interchange).

E-commerce merupakan perjanjian melalui online contract yang pada prinsipnya sama dengan perjanjian pada umumnya. Perbedaannya hanya 
terletak pada medianya dalam membuat perjanjian. Pendek kata, yang menjadi perubahan besar adalah cara/mekanisme transaksi perdagangan yang semula dengan alternatif metode transaksi yang berdasarkan kertas (paper-based methods) menjadi transaksi yang berdasarkan komunikasi elektronik (communication and storage of information).

Term shari' 'ah atau shara' menurut kata dasarnya berarti jalan ke sumber air atau jalan terang yang harus dilalui/diikuti oleh orang-orang beriman (Dāirah al-Ma'ārif al-Islāmiyyah, tt: 242). Sedangkan secara terminologi, shari' ah berarti aturan-aturan atau hukum-hukum Allah s.w.t. yang tertuang dalam Alquran dan Sunnah. Aturan-aturan ini meliputi kompleksitas kebutuhan manusia baik yang bersifat individual maupun kolektif. Kompleksitas dapat juga diartikan sebagai hal yang komprehensif dan universal. Komprehensif berarti mencakup seluruh aspek kehidupan baik ritual (ibadah) maupun sosial (muamalah). Sedangkan universal bermakna bahwa syariat Islam tidak dibatasi oleh dimensi tempat atau waktu.

Dari definisi tersebut dapat ditarik benang merah bahwa ada hubungan integratif antara normative (syariat) dengan positif (muamalah). Artinya dalam pandangan Islam tidak perlu mendikotomikan antara etika (norma agama) dan realita (aktifitas sosial) secara absolut sebagaimana pemahaman Max Weber tentang wertfrei bahwa nilai tidak dapat disatukan dengan ilmu pengetahuan, masalah kepercayaan tidak dapat diselesaikan dengan ilmiah (Koesters, 1994: 154). Pendek kata, syariah sebagai norma tidak dapat dipisahkan dari aktifitas sosial termasuk kegiatan ekonomi seperti perdagangan.

\section{Varian dan Bentuk Perjanjian dalam Perniagaan Online}

Tahapan yang dilakukan dalam proses bertransaksi di dunia maya pada umumnya adalah, pertama information sharing, yakni perusahaan menawarkan produk-produknya dengan menjaring calon pembeli sebanyakbanyaknya melalui internet atau website-nya, sementara pembeli leluasa memilih transaksi mana yang sesuai dengan yang ia cari, dengan menjelajah situs di internet pembeli layaknya orang yang sedang berbelanja secara konvensional dengan melihat etalase-etalase yang dipajang di toko. Pembeli berusaha sedapat mungkin mencari produk atau jasa yang diinginkan dan 
mencari data atau informasi tertentu yang dibutuhkan sehubungan dengan proses transaksi jual beli yang akan dilakukan. Jika tertarik dengan produk yang ditawarkan, konsumen dapat melakukan transaksi perdagangan dengan cara melakukan pemesanan secara elektronik (online orders), yakni melalui penggunaan perangkat komputer dan jaringan internet.

Para pihak yang bertransaksi harus melakukan perjanjian tertentu sehingga proses pembelian dapat dilakukan dengan sah, benar dan aman. Pembelian antara dua entitas bisnis biasanya dilakukan melalui jaringan tertentu, seperti EDI (Electronic Data Interchange) atau ekstranet. Di dalam proses bisnis ini, ada empat aliran entitas yang harus dikelola dengan baik, yaitu (Indrajit, 2001: 7-8):

1. Flow of goods (aliran produk)

2. Flow of information (aliran informasi)

3. Flow of money (aliran uang)

4. Flow of documents (aliran dokumen).

Fasilitas e-commerce yang ada harus dapat mengintegrasikan keempat aliran tersebut sehingga proses transaksi dapat dilakukan secara efisien, efektif dan terkontrol dengan baik. Pada suatu pertukaran data elektronik (Electronic Data Interchanges), lazimnya, para pihak mengikuti suatu metode pertukaran data bisnis yang bersifat standar dengan format yang lazim dan telah disepakati bersama oleh para pihak tersebut, seperti yang diatur dalam konsep Electronic Data Interchanges Agreement di Eropa. Beberapa pokok dari konsep EDI masyarakat Eropa yang mengacu pada UNCITRAL model law on Electronic Commerce (1996/1998), telah menjadi pedoman dalam proses transaksi EDI (Dewi, 2005: 202).

Perniagaan secara elektronik memang relatif baru dikenal, namun dalam prakteknya e-commerce sebenarnya telah berjalan di Indonesia dalam berbagai varian. Hal ini dibuktikan oleh banyaknya penggunaan teknologi Electronic Data Interchange (EDI) dan Electronic Funds Transfer Credit Cards, Automated Teller Machines, dan Telephone Banking dalam berbagai kegiatan perniagaan di Indonesia.

Pada umumnya, makna "transaksi" sering kali direduksi sebagai perjanjian jual beli antar para pihak yang bersepakat untuk itu. Padahal dalam 
perspektif yuridis, terminologi transaksi tersebut pada dasarnya adalah keberadaan suatu perikatan ataupun hubungan hukum yang terjadi antara para pihak. Oleh karena itu, keberadaan ketentuan-ketentuan hukum mengenai perikatan tetap mengikat walaupun terjadi perubahan media maupun perubahan tata cara bertransaksi. Pendek kata, transaksi secara elektronik, pada dasarnya adalah perikatan ataupun hubungan hukum yang dilakukan secara elektronik dengan memadukan jaringan dari sistem elektronik berbasiskan komputer dengan sistem komunikasi, yang selanjutnya difasilitasi oleh keberadaan jaringan komputer global atau internet. Dalam lingkup keperdataan, khususnya aspek perikatan, makna transaksi tersebut akan merujuk kepada semua jenis dan mekanisme dalam melakukan hubungan hukum secara elektronik itu sendiri.

Dalam pengaturan perniagaan online, dapat diterapkan KUH Perdata secara analogis, yakni dapat diterapkan ketentuan dari Buku II tentang Hukum Perikatan dan KUH Dagang. Dalam KUH Perdata ditentukan bahwa suatu persetujuan adalah suatu perbuatan di mana satu orang atau lebih mengikatkan dirinya terhadap satu orang lain atau lebih (pasal $1313 \mathrm{KUH}$ Perdata). Untuk sahnya suatu kontrak, kita harus melihat syarat-syarat yang diatur di dalam pasal 1320 KUH Perdata yang menentukan bahwa syarat sahnya suatu perjajian adalah sebagai berikut:

1. kesepakatan para pihak

2. kecakapan untuk membuat perjanjian

3. suatu hal tertentu; dan

4. suatu sebab yang halal.

Apabila unsur pertama (kesepakatan) dan unsur kedua (kecakapan) tidak terpenuhi, maka kontrak tersebut dapat dibatalkan. Sedangkan apabila tidak terpenuhi unsur ketiga (suatu hal tertentu) dan unsur keempat (suatu sebab yang halal) maka kontrak tersebut adalah batal demi hukum.

Suatu persetujuan tidak hanya mengikat apa yang dengan tegas ditentukan di dalamnya, melainkan juga segala sesuatu yang menurut sifatnya persetujuan dituntut berdasarkan keadilan, kebiasaan atau undang-undang (pasal 1339 KUH Perdata). Syarat-syarat yang selalu diperjanjikan menurut kebiasaan, harus dianggap telah termasuk dalam suatu persetujuan, walaupun 
tidak dengan tegas dimasukkan di dalamnya (pasal 1347 KUH Perdata).

Pasal 1346 KUH Perdata memberikan keleluasaan lebih di mana suatu perjanjian mengikuti standar kebiasaan dalam negeri atau di tempat perjanjian telah dibuat (jika meragukan isinya). Oleh karenanya, walaupun secara yuridis tidak jelas ditekankan pengaturan mengenai tata cara pelaksanaan, jika hal tersebut sudah diakui sebagai suatu kebiasaan dalam perjanjian yang menggunakan media elektronik, maka kebiasaan tersebut mendapatkan pengakuan yuridis (Raharjo, 2006).

\section{Istilah Hukum Perjanjian/Perikatan Menurut KUH Perdata dan Hukum Islam}

Dalam perikatan Islam dikenal istilah al-'aqdu (akad) yang secara etimologi berarti ikatan. Kemudian dikenal pula istilah al-'ahdu (janji). Menurut Djamil, istilah al-'aqdu ini dapat disamakan dengan istilah verbintenis dalam KUH Perdata (Djamil, 2001: 247). Sedangkan istilah al-'ahdu dapat disamakan dengan istilah perjanjian atau overeenkomst, yaitu suatu pernyataan dari seseorang untuk mengerjakan atau tidak mengerjakan sesuatu yang tidak berkaitan dengan orang lain (Badrulzaman, 2001: 248). Sedangkan jumhur ulama memberikan definisi akad sebagai: "pertalian antara ijab dan kabul yang dibenarkan oleh syara' yang menimbulkan akibat hukum terhadap objeknya. Abdoerraoef mengemukakan terjadinya suatu perikatan (al-'aqdu) melalui tiga tahap, yaitu sebagai berikut (Dewi, 2005: 46):

1. Al-'ahdu (perjanjian), yaitu pernyataan dari seseorang untuk melakukan sesuatu atau tidak melakukan sesuatu dan tidak ada sangkut pautnya dengan kemauan orang lain. Janji ini mengikat orang yang menyatakannya untuk melaksanakan janjinya tersebut, seperti yang difirmankan oleh Allah SWT dalam Surat Ali Imran ayat 76.

2. Persetujuan, yaitu pernyataan setuju dari pihak kedua untuk melakukan sesuatu atau tidak melakukan sesuatu sebagai reaksi terhadap janji yang dinyatakan oleh pihak pertama. Persetujuan tersebut harus sesuai dengan janji pihak pertama.

3. Apabila dua buah janji dilaksanakan, maksudnya oleh para pihak, maka terjadilah apa yang dinamakan " "aqdu”. Hal ini terdapat dalam Alquran 
surat al-Māidah ayat 1. Dengan demikian yang mengikat masing-masing pihak sesudah pelaksanaan perjanjian itu bukan lagi perjanjian atau “'ahdu” itu, tetapi “'aqdu”. Sebagai contoh, jika A menyatakan janji untuk membeli sebuah mobil kemudian B menyatakan janji untuk menjual sebuah mobil, maka A dan B berada pada tahap “'ahdu”. Apabila merek dan harga mobil disepakati oleh kedua belah pihak, maka terjadi persetujuan. Jika dua janji tersebut dilaksanakan, misalnya dengan membayar uang tanda jadi terlebih dahulu oleh A, maka terjadi perikatan atau "aqdu" di antara keduanya.

Proses suatu perikatan ini tidak terlalu berbeda dengan proses perikatan yang dikemukakan oleh Soebekti. Ia memberi pengertian perikatan sebagai suatu perhubungan hukum antara dua orang atau dua pihak, berdasarkan mana pihak yang satu berhak menuntut sesuatu hal daripada pihak yang lain. Pihak yang lain berkewajiban untuk memenuhi tuntutan itu (Soebekti, 1992: 14). Sedangkan pengertian perjanjian menurut Soebekti adalah suatu peristiwa di mana seseorang berjanji kepada seorang lainnya atau di mana dua orang itu saling berjanji untuk melaksanakan sesuatu hal. Peristiwa perjanjian ini menimbulkan hubungan di antara orang-orang tersebut yang disebut dengan perikatan. Dengan demikian, hubungan antara perikatan dengan perjanjian adalah perjanjian melahirkan perikatan, seperti yang tercantum dalam Pasal 1233 KUH Perdata, bahwa perjanjian merupakan salah satu sumber perikatan.

Perbedaan yang terjadi dalam proses perikatan antara hukum Islam dan KUH Perdata adalah pada tahap perjanjiannya. Dalam hukum perikatan Islam, janji pihak pertama terpisah dari janji pihak kedua (merupakan dua tahap), baru kemudian lahir perikatan. Sedangkan pada KUH Perdata, perjanjian antara pihak pertama dan pihak kedua adalah satu tahap yang kemudian menimbulkan perikatan di antara mereka (Dewi, 2005: 47).

\section{Perniagaan Online dalam Perspektif Hukum Perikatan Islam}

Islam bukanlah agama yang rigid dan beku. Ajarannya selalu berkembang dinamis mengikuti perkembangan zaman, ilmu dan teknologi, tidak terbelenggu oleh ruang dan waktu. Keuniversalannya akan tampak 
jelas terutama dalam bidang muamalah, karena bidang muamalah cakupannya luas dan dinamis, bahkan tidak memberikan special treatment bagi muslim dan tidak membedakannya dari nonmuslim (Hafidhuddin, 2003: 49).

Perniagaan merupakan cara bagi umat manusia untuk mempertahankan hidup dan bersosialisasi dengan sesamanya dan ini berlaku sejak umat manusia itu ada. Yang membedakan adalah materi yang diperdagangkan dan metode yang dipakai dalam bertransaksi. Allah dan Rasul-Nya telah menetapkan pertukaran barang dengan persetujuan antara kedua belah pihak dalam suatu transaksi dagang sebagai sesuatu yang halal atau dibolehkan, dan melarang mengambil benda orang lain tanpa persetujuan dan izin dari mereka. Selain untuk menjaga perdamaian dan ketertiban dalam masyarakat, hal ini juga sangat penting untuk memelihara hubungan yang baik dan harmonis di kalangan anggota masyarakat. Rasulullah telah meletakkan dasardasar hukum dan peraturan guna melakukan transaksi-transaksi dan juga memberikan hak untuk meneruskan dan membatalkan transaksi dengan syarat-syarat tertentu (Rahman, 2000: 15).

Suatu perniagaan/jual beli dapat dikatakan sah apabila telah memenuhi rukun dan syarat yang telah ditentukan oleh syara'. Mengenai rukun dan syarat perniagaan/jual beli, para ulama berbeda pendapat, namun menurut pendapat jumhur ulama, rukun jual beli ada empat, yakni (Hasan, 2003: 118): 1) Orang yang berakad (penjual dan pembeli); 2) Șighat (lafal ijab dan kabul); 3) Objek transaksi (barang yang diperjualbelikan); 4) Ada nilai tukar pengganti barang.

Untuk mengetahui apakah perniagaan online dilarang atau tidak, ditinjau dari sudut pandang hukum perikatan Islam, maka perlu dikomparasikan dengan syarat dan rukunnya.

\section{Subjek Perikatan/Orang yang berakad (al-‘āqid)}

Subjek hukum yang notabene sebagai pelaku perbuatan hukum sering kali diartikan sebagai pihak pengemban hak dan kewajiban. Subjek hukum ini terdiri dari dua macam yaitu manusia dan badan hukum.

Ulama Malikiyah dan Hanafiyah mensyaratkan 'āqid harus berakal, yakni sudah mumayyiz. Mumayyiz adalah anak yang beranjak besar, mampu 
berbicara dan jawaban yang dilontarkan dapat dipahami, serta berumur minimal 7 tahun. Oleh karena itu, dipandang tidak sah suatu akad yang dilakukan oleh anak kecil yang belum mumayyiz, orang gila dan lain-lain. Adapun ulama Syafi'iyyah dan Hanabilah mensyaratkan 'āqid harus baligh, berakal, mampu memelihara agama dan hartanya (Firdaus, 2005: 17).

Sedangkan badan hukum adalah suatu badan yang dianggap dapat bertindak dalam hukum dan yang mempunyai hak-hak, kewajiban-kewajiban dan perhubungan hukum terhadap orang lain atau badan lain (Prodjodikoro, 1981: 23). Keberadaan badan hukum dalam ketentuan hukum Islam memang tidak diatur secara jelas dan terperinci, namun ada beberapa dalil yang menunjukkan badan hukum dengan menggunakan istilah al-shirkah, seperti tercantum dalam QS. Al-Nisā' (4): 12, QS. Shād (38): 24, dan Hadits Qudsi riwayat Abu Dawud dan al-Hạkim dari Abu Hurairah, bahwa Nabi Muhammad saw. bersabda, “Aku (Allah) adalah pihak ketiga dari dua orang yang berserikat, sepanjang salah seorang dari keduanya tidak berkhianat terhadap lainnya. Apabila seseorang berkhianat terhadap lainnya, maka Aku keluar dari keduanya." Adanya kerjasama di antara beberapa orang menimbulkan kepentingan-kepentingan dari shirkah tersebut terhadap pihak ketiga. Dalam hubungannya dengan pihak ketiga inilah timbul bentuk baru dari subjek hukum yang disebut dengan badan hukum (Dewi, 2005: 59).

Dalam transaksi perniagaan online, perintah pembayaran melalui beberapa pihak selain dari pembeli (cardholder) dan penjual (merchant) juga melibatkan payment gateway, aquirer dan issuer. Masing-masing pihak yang terlibat dalam transaksi harus memenuhi ketentuan-ketentuan untuk validitas transaksi itu sendiri. Pembeli dan penjual harus memenuhi ketentuan memiliki kecakapan yang sempurna dan mempunyai wewenang untuk melakukan transaksi.

Dalam perniagaan elektronik, consumer diminta untuk mengisi informasi pembayaran (yang biasanya disertai dengan memasukkan kode rahasia) pada form slip pembelian yang telah disediakan website merchant yang kemudian dilakukan otorisasi melalui payment gateway. Dari otorisasi tersebut dapat diketahui bahwa ia benar-benar pemilik yang sah dan berwenang menggunakannya. Pada pihak penjual, merchant memiliki sertifikat digital dari Certificate Authority (CA) yang menjamin identitas 
pihak tesebut bahwa ia benar-benar ada dan memiliki wewenang untuk melakukan transaksi online. Yang penting dalam melaksanakan online contract adalah kedua pihak harus mengerti tentang pengoperasian komputer dan internet, dan hal ini tidak mungkin dilakukan oleh orang yang tidak memiliki kecakapan yang sempurna, seperti dilakukan oleh anak-anak yang belum berakal atau orang gila (Asnawi, 2004: 76). Jadi dengan demikian, perniagaan online telah memenuhi salah satu rukun di atas.

\section{Șíghat (Lafal Ijab dan Kabul)}

Șighat akad adalah sesuatu yang disandarkan dari dua pihak yang berakad yang menunjukkan atas apa yang ada di hati keduanya tentang terjadinya suatu akad. Hal ini dapat diketahui dengan ucapan perbuatan, isyarat dan tulisan. Șighat tersebut biasa disebut ijab dan kabul (Syafei, 2004: 46).

Definisi ijab menurut ulama Hanafiyah adalah penetapan perbuatan tertentu yang menunjukkan keridaan yang diucapkan oleh pihak pertama, baik yang menyerahkan maupun yang menerima. Sedangkan kabul adalah orang yang berkata setelah orang yang mengucapkan ijab, di mana perkataan tersebut menunjukkan keridaan atas ucapan orang yang pertama (Abidin, $\mathrm{tt}: 4-6)$.

Metode șighat atau ijab kabul dalam akad dapat dilakukan dengan beberapa cara (Firdaus, 2005: 15):

1. Akad dengan lafal (ucapan); Akad dengan lafal yang dipakai untuk ijab dan kabul harus jelas pengertiannya, harus bersesuaian antara ijab dan kabul, begitu pula harus sungguh-sungguh, karena jika tidak ada iktikad kesungguhan, maka akad menjadi tidak sah. Atas dasar itulah para fukaha berpendapat bahwa berjanji menjual itu belum merupakan akad penjualan, dan orang yang berjanji itu tidak dapat dipaksa menjualnya.

2. Akad dengan tulisan; Diperbolehkan pula akad dengan tulisan, baik bagi mereka yang mampu berbicara maupun tidak, dengan syarat tulisan tersebut harus jelas, tampak dan dapat dipahami oleh kedua belah pihak, sebab tulisan dalam qāidah fiqhiyyah, "tulisan bagaikan ucapan”. Ulama Syafi'iyah dan Hanabilah berpendapat bahwa akad dengan tulisan adalah 
sah jika kedua belah pihak yang berakad tidak hadir. Namun jika keduanya hadir, tidak diperkenankan menggunakan tulisan, sebab tulisan tidak dibutuhkan.

3. Akad dengan perbuatan; Dewasa ini akad dengan perbuatan menjadi lumrah, kendatipun tidak harus diucapkan, namun cukup dengan perbuatan yang menunjukkan saling meridai.

4. Akad dengan isyarat; Bagi orang yang mampu berbicara tidak dibenarkan akad dengan isyarat, melainkan harus dengan menggunakan lisan, tulisan atau perbuatan. Adapun bagi yang tidak dapat berbicara, boleh menggunakan isyarat, tetapi jika mampu menulis dan bagus, maka dianjurkan atau lebih baik dengan tulisan.

Adapun korelasi persyaratan mengenai ijab kabul dalam perniagaan online adalah:

a. Kejelasan ijab dan Kabul (Jalā-u al-ma'na)

Akad dapat dilakukan dengan cara lisan maupun tulisan, yang penting adalah antara ijab dengan kabulnya jelas, pasti dan dapat dipahami oleh kedua belah pihak yang mengadakan perikatan.

Dari uraian ini jelas, bahwa transaksi perniagaan online memenuhi syarat, karena dalam transaksi tersebut ijab kabul dari suatu akad yang mencerminkan tujuan dari diadakannya akad tersebut dilakukan dengan cara tulisan yang pengirimannya dilakukan melalui pertukaran data elektronik. Format dari ijab kabulnya dalam bentuk tulisan tentu saja dapat dengan jelas dipahami oleh kedua belah pihak yang mengadakan transaksi, jika kedua belah pihak saling setuju dengan penawaran dan penerimaan yang ada.

b. Kesesuaian antara ijab dan kabul (Ittiṣāl al-qabūl bi al-ijāb/tawāfuq)

Jual beli lazimnya dilakukan dalam satu majelis/tempat. Namun jika syarat barang itu jelas terperinci sesuai dengan informasi yang diberikan penjual kepada pembeli, maka jual beli dapat dilakukan dalam satu "majelis" maya, dan jual beli tersebut adalah sah.

Dalam transaksi perniagaan online, pembeli dan penjual tidak berada dalam satu tempat tertentu dalam arti fisik dan bisa saja transaksi dilakukan oleh subjek hukum dalam berbagai negara yang berbeda. 
Penawaran dapat dilakukan melalui situs-situs atau melalui provider di mana dalam penawaran tersebut mencakup informasi mengenai objek transaksi secara jelas dan terperinci. Jika ada suatu perbedaan antara informasi yang diberikan dalam situs dengan barang yang dijual dan telah dilakukan pembayaran terhadap barang tersebut, maka pembeli dapat komplain kepada penjual atau mengembalikan barang tersebut serta mengambil kembali uang yang telah dibayarkan sesuai perjanjian sebelumnya.

c. Menunjukkan kehendak para pihak (jazmu al-Irādataini)

Menunjukkan kehendak para pihak dapat diartikan dengan pernyataan mengungkapkan kehendak mereka yang harus mencerminkan sikap sukarela. Jika penerima penawaran tidak menyetujui penawaran tersebut, ia tidak perlu melakukan transaksi melalui cara yang disebutkan di atas. Hal ini mencerminkan suatu kesukarelaan dalam melakukan transaksi perniagaan online. Untuk memastikan bahwa penerima tawaran telah menerima suatu penawaran dan melakukan transaksi secara sukarela, adalah dari kenyataan bahwa pembeli melakukan suatu transaksi tanpa ada paksaan karena ia membuka situs dengan keinginannya sendiri atau dengan kesukarelaan.

Adapun tujuan yang terkandung dalam pernyataan ijab dan kabul harus jelas dan terdapat kesesuaian, sehingga dapat dipahami oleh masingmasing pihak. Selain itu pelaksanaan ijab dan kabul juga harus berhubungan langsung dalam suatu majelis. Apabila kedua belah pihak hadir dan saling bertemu dalam suatu tempat untuk melaksanakan transaksi, maka tempat tersebut dinamakan majelis akad. Namun demikian transaksi dapat diperbolehkan pula diadakan di tempat yang berbeda, tetapi sudah dimaklumi oleh keduanya, sehingga keduanya saling memahami (Syafei, 2004: 52).

Jumhur ulama berpendapat, apabila transaksi di atas sudah menjadi adat kebiasaan suatu masyarakat, maka jual beli semacam itu hukumnya boleh, asalkan dalam aktivitas jual beli tersebut telah terpenuhi unsur sukarela (suka sama suka) antara kedua belah pihak (Hasan, 2003: 122), sebagaimana dimaksudkan dalam surat al-Nisā': 29 yang berbunyi: 


\section{إلا أن تكون تجارة عن تراض منكم}

Artinya:

“...Kecuali dengan jalan perniagaan yang berlaku dengan suka sama suka di antara kamu...

Dalam transaksi perniagaan online, consumer dan merchant bertemu dalam satu majelis yaitu "majelis maya". Pembeli dan penjual tidak berada dalam satu tempat tertentu dalam arti secara fisik dan bisa saja transaksi dilakukan dari berbagai negara yang berbeda. Jika ada suatu perbedaan antara informasi yang diberikan dalam situs, dengan barang yang dijual dan telah dilakukan pembayaran terhadap barang tersebut, maka pembeli dapat memberitahukan kepada pihak penjual atau mengembalikan barang tersebut dan mengambil uang yang telah ia bayarkan. Tetapi, suatu kesalahan tidak dapat dikoreksi jika pihak pembeli telah menggunakan barang atau produk tersebut (Dewi, 2005: 209).

Pada dasarnya pernyataan kesepakatan pada transaksi perniagaan online sama dengan pernyataan kesepakatan sebagaimana transaksi dalam perikatan Islam, pernyataan kesepakatan dapat dilakukan dengan berbagai cara dan melalui berbagai media, namun substansinya adalah pernyataan tersebut dapat dipahami maksudnya oleh kedua pihak yang melakukan transaksi, sehingga dapat dimanifestasikan sebagai kerelaan kedua pihak.

\section{Objek Transaksi (Barang yang Diperjualbelikan/Ma'qūd 'alaih)}

Ma'qud 'alaih adalah sesuatu yang dijadikan objek akad dan dikenakan padanya akibat hukum yang ditimbulkan. Bentuk objek akad dapat berupa benda berwujud, seperti mobil dan rumah, maupun benda tidak berwujud, seperti manfaat. Syarat-syarat yang harus dipenuhi dalam objek transaksi (mahallu al-'aqd) adalah sebagai berikut (Mas'adi, 2002: 86-89):

a. Objek perikatan telah ada ketika akad dilangsungkan

Suatu perikatan yang objeknya tidak ada adalah batal, seperti menjual anak hewan yang masih di dalam perut induknya atau menjual tanaman 
sebelum tumbuh. Alasannya, bahwa sebab hukum dan akibat akad tidak mungkin bergantung pada sesuatu yang belum ada. Namun demikian, terdapat pengecualian terhadap bentuk akad-akad tertentu, seperti salām dan istiṣnā'.

b. Objek perikatan dibenarkan oleh syariah.

Pada dasarnya, benda-benda yang menjadi objek perikatan haruslah memiliki nilai dan manfaat bagi manusia. Benda-benda yang sifatnya tidak suci, seperti bangkai, minuman keras, babi, atau darah dianggap tidak memiliki nilai dan manfaat bagi manusia. Menurut golongan Hanāfiyyah, kesucian objek akad tidak disyaratkan. Dengan demikian, jual beli kulit bangkai dibolehkan sepanjang memiliki manfaat, kecuali benda-benda yang secara jelas dinyatakan dalam nas, seperti khamar, daging babi, bangkai dan darah. Selain itu, jika objek perikatan itu dalam bentuk manfaat yang bertentangan dengan ketentuan syariah, seperti pelacuran, pembunuhan dan sejenisnya, juga tidak dapat dibenarkan, artinya transaksi demikian menjadi batal.

c. Objek akad harus jelas dan dikenali

Suatu benda yang menjadi objek perikatan harus memiliki kejelasan dan diketahui oleh 'āqid. Hal ini bertujuan agar tidak terjadi kesalahpahaman di antara para pihak yang dapat menimbulkan sengketa. Jika objek tersebut berupa benda, maka benda tersebut harus jelas bentuk, fungsi dan keadaannya. Jika terdapat cacat pada benda tersebut pun harus diberitahukan. Jika objek tersebut berupa jasa, harus jelas sejauh mana kemampuan, ketrampilan dan kepandaian pihak yang memiliki keahlian dalam bidang tersebut. Jika pihak tersebut belum atau kurang ahli, terampil, mampu maupun pandai, tetap harus diberitahukan agar masingmasing pihak memahaminya. Dalam hadits riwayat Imam lima dari Abu Hurairah, disebutkan bahwa Nabi Muhammad saw. melarang jual beli yang di dalamnya ada penipuan (gharar) dan jual beli hașāh (jual beli dengan syarat tertentu, seperti penjual akan menjual bajunya apabila lemparan batu dari penjual mengenai baju itu).

d. Objek dapat diserahterimakan.

Benda yang menjadi objek perikatan dapat diserahkan pada saat akad terjadi, atau pada waktu yang telah disepakati. Oleh karena itu, disarankan 
bahwa objek perikatan berada dalam kekuasaan pihak pertama agar mudah untuk menyerahkannya kepada pihak kedua. Burung di udara dan ikan di laut termasuk tidak dapat diserahkan, karena tidak ada dalam kekuasaannya. Untuk objek perikatan yang berupa manfaat, maka pihak pertama harus melaksanakan tindakan (jasa) yang manfaatnya dapat dirasakan oleh pihak kedua, sesuai dengan kesepakatan.

Ulama fikih sepakat bahwa barang yang dijadikan akad harus sesuai dengan ketentuan syara', seperti objek yang halal, dapat diberikan pada waktu akad, diketahui oleh kedua belah pihak dan harus suci (Al-Kasāni, tt: 140). Bentuk objek akad dapat berupa benda berwujud dan benda yang tidak berwujud. Mengenai komoditi yang dijadikan objek transaksi dalam e-commerce tergantung pada penawaran pihak merchant dan pemesanan dari pihak consumer, jenis komoditi apa dan bagaimana yang akan dibeli.

Komoditi yang diperdagangkan dalam perniagaan online dapat berupa komoditi digital dan komoditi non-digital. Untuk komoditi digital seperti electronic newspaper, digital library dan sejenisnya, dapat langsung diserahkan kepada consumer melalui media internet. Sedangkan komoditi nondigital tidak dapat diserahkan langsung melalui media internet, namun dikirimkan melalui jasa kurir sesuai dengan kesepakatan spesifikasi komoditi waktu dan tempat penyerahan.

Dengan demikian objek yang dijadikan komoditi dalam transaksi online dapat diklasifikasikan sebagai berikut: Objek transaksi wajib memenuhi kriteria dan syarat-syarat yang telah ditentukan oleh syariat Islam seperti komoditi yang halal, mempunyai nilai dan manfaat bagi manusia dan memiliki kejelasan baik bentuk, fungsi dan keadaannya serta dapat diserahterimakan pada waktu dan tempat yang disepakati. Artinya transaksi yang diadakan oleh para pihak itu bukan perbuatan yang bertentangan dengan hukum atau perbuatan yang melawan hukum syar'i. Jika objek transaksi memenuhi kriteria di atas maka hukumnya sah secara syar'i. Perjanjian yang bertentangan dengan ketentuan hukum syar'i adalah tidak sah, dan dengan sendirinya tidak ada kewajiban bagi masing-masing pihak untuk menepati atau melaksanakan perjanjian tersebut, atau dengan perkataan lain apabila isi perjanjian itu merupakan perbuatan yang melawan hukum (hukum syar'i), maka perjanjian yang diadakan dengan sendirinya batal demi hukum. 
Dalam perjanjian yang menggunakan media elektronika terdapat beberapa kemungkinan terjadinya kesalahan dalam komunikasi atau masuknya "hackers" yang mengacaukan transaksi dan kemudian baru diketahui ternyata barang yang dimaksud oleh penjual disalahtafsirkan oleh pembeli. Hal ini tentunya menjadi masalah dalam perikatan menurut Islam. Kemungkinan terjadi kesalahan harga dalam sistem komunikasi secara elektronik sangat besar terjadi, hal ini tentu merugikan salah satu pihak, sehingga hal ini dimasukkan unsur kekhilafan dan penipuan serta menjadi syarat untuk meminta pembatalan terhadap perjanjian atau perikatan yang sudah dibuat.

\section{Nilai Tukar Pengganti Barang}

Para ulama bersepakat bahwa nilai tukar pengganti barang dalam transaksi harus dapat ditentukan dan diketahui oleh pihak-pihak yang terlibat dalam transaksi. Ketentuan ini dimaksudkan untuk menghilangkan ketidakjelasan yang dapat menimbulkan perselisihan di kemudian hari. Sebagai contoh misalnya pembayaran dilakukan dengan uang, harus dijelaskan jumlah dan mata uang yang digunakan, atau apabila dengan barang, maka harus dijelaskan jenis, kualitas dan sifatnya.

Dalam transaksi perniagaan online melalui internet, sebelum proses pembayaran dilakukan, masing-masing pihak telah menyepakati mengenai jumlah dan jenis mata uang yang digunakan sebagai pembayaran/harga serta metode pembayaran yang digunakan, misalnya dengan kartu kredit/debit. Pada waktu kedua belah pihak telah mencapai kesepakatan yang diikuti proses pembayaran, keduanya melibatkan dua bank perantara/wakil dari masing-masing pihak, yaitu issuer dan acquirer. Consumer memerintahkan kepada issuer untuk dan atas nama consumer melakukan sejumlah pembayaran atas harga barang kepada acquirer yang ditujukan kepada merchant. Setelah pembayaran diterima oleh merchant, proses selanjutnya adalah pemenuhan prestasi oleh pihak merchant berupa pengiriman barang sesuai dengan kesepakatan mengenai saat penyerahan dan spesifikasi barang.

Sesuatu yang dijadikan pembayaran/harga dalam transaksi perniagaan online adalah uang yang telah diketahui jumlah dan jenis mata 
uangnya. Uang yang dijadikan pembayaran/harga diserahkan melalui wakil/ perantara dari masing-masing pihak yang bertransaksi yang dalam hal ini adalah issuer dan acquirer. Pembayaran segera dilakukan sesuai dengan jumlah dan mata uang yang telah disepakati setelah proses otorisasi berhasil dilaksanakan. Berbagai cara biasanya dilakukan oleh perusahaan maupun bank untuk membuktikan kepada consumer bahwa proses pembayaran telah dilakukan dengan baik, seperti pemberitahuan melalui e-mail atau situs terkait yang berisi berita acara jual beli dan kuitansi pembelian yang menjelaskan secara rinci tentang jenis produk atau jasa yang dibeli. Berita acara tersebut juga menjelaskan mengenai metode pembayaran yang telah dilakukan atau pencatatan transaksi pembayaran oleh bank yang laporannya akan diberikan secara periodik pada akhir bulan (Asnawi, 2004: 127).

Pembayaran/harga dalam transaksi perniagaan online pada prinsipnya telah memenuhi ketentuan-ketentuan yang ada dalam sistem perikatan Islam. Pembayaran/harga dalam transaksi e-commerce merupakan sesuatu yang bernilai dan bermanfaat. Uang yang digunakan sebagai instrumen pembayaran pengganti barang dapat ditentukan dan diketahui oleh pihakpihak yang terlibat dalam transaksi dan dibayarkan segera sesuai kesepakatan setelah semua proses otorisasi selesai dilaksanakan.

\section{Penutup}

Perniagaan secara online (e-commerce) melalui internet sebagai basis transaksi, pada dasarnya hampir sama dengan perniagaan yang dilakukan secara konvensional, yang membedakan hanyalah medianya yang melalui ruang maya (cyber space) dan bentuk kontrak perjanjiannya yang semula secara konvensional menggunakan media kertas dan tinta basah, kemudian beralih menjadi serba digital. Dalam transaksi konvensional untuk sahnya suatu kontrak harus memenuhi syarat-syarat yang diatur di dalam Pasal 1320 KUH Perdata. Sejatinya antara Pasal 1320 KUH Perdata dengan sistem perikatan Islam dalam prakteknya tidak perlu ada garis dikotomis yang saling mempertentangkan antara keduanya. Sepanjang perniagaan secara elektronik memenuhi ruh ketentuan-ketentuan sistem perikatan Islam, baik rukun dan syarat-syaratnya, maka perdagangan semacam itu adalah sah-sah saja dan 
tidak bertentangan dengan perniagaan yang mendasarkan pada sistem perikatan Islam secara konvensional. Hukum Islam bukanlah sekumpulan peraturan rigid dan statis, yang alergi terhadap perubahan. Hukum Islam adalah hukum yang dapat berkembang dinamis sesuai 'urf setempat. Pendek kata, tentu saja transaksi e-commerce syariah adalah hal yang tak terelakkan, dan hal ini tentu menjadi tantangan baru bagi kewenangan Pengadilan Agama mendatang.

\section{Daftar Pustaka}

‘Ābidin, Ibnu. tt. Radd al-Mukhtār 'alā Dār Al-Mukhtār, juz II. Mesir: alMunirah.

Al-Kasāni, Alāu al-dīn. Badā-i' al-Ṣanā-i’ fỉ Tartībi al-Sharā-i', juz V. Mesir: Shirkah al-Mațbū'ah.

Asnawi, Haris Faulidi. 2004. Transaksi Bisnis E-Commerce Perspektif Islam. Yogyakarta: Magistra Insania Press.

Dāirah al-Ma'ārif al-Islāmiyyah. tt. Beirut: Dār al-Fikr, vol. III.

Dewi, Gemala dkk. 2005. Hukum Perikatan Islam di Indonesia. Jakarta: Prenada Media.

Djamil, Faturrahman. 2001. "Hukum Perjanjian Syariah" dalam Kompilasi Hukum Perikatan oleh Mariam Darus Badrulzaman et al, cet.1. Bandung: Citra Aditya Bakti.

Fajar, Mukti Fajar. Aspek Hukum Pembuktian Digital Evidence dalam Eelectronic Commerce. Makalah Resume Tesis. Fakultas Hukum UMY.

Firdaus NH, Muhammad NH dkk. 2005. Cara Mudah Memahami Akad-Akad Syariah. Jakarta: Renaisan.

Hafidhuddin, Didin dan Hendri Tanjung. 2003. Manajemen Syariah dalam Praktek. Jakarta: Gema Insani.

Hasan. M. Ali. 2003. Berbagai Macam Transaksi dalam Islam (Fiqh Muamalat). Jakarta: PT. Raja Grafindo Persada.

Indrajit, Richardus Eko. 2001. E-Commerce: Kiat dan Strategi Bisnis di Dunia Maya. Jakarta: PT. Elex Media Komputindo.

Koesters, Paul Heinz. 1994. Tokoh-tokoh Ekonomi Mengubah Dunia. Jakarta: Gramedia.

Makarim, Edmon. 1992. Legal Framework: Policy and Regulation of Electronic Commerce. 
Mas'adi, Ghufron A. 2002. Fiqh Muamalah Kontekstual, cet. 1. Jakarta: Raja Grafindo Persada.

Raharjo, Ignasius Sumarsono. 2006. Informasi Elektronik pada ElectronicCommerce dalam Hukum Pembuktian Perdata. Post Graduate Airlangga University.

Rahman, Muhammad Afzalur. 2000. Encyclopedia of Seerah (Muhammad sebagai Seorang Pedagang), alih bahasa Dewi Nurjulianti dkk., cet.3. Jakarta: Yayasan Swarna Bhumy.

Richard Hill and Ian Wolden. 2004. "Electronic Commerce: Technical, Business, and Legal Issues," 11 Februari 2004.

Soebekti. 1992. Hukum Perjanjian, cet.14, Jakarta: Intermasa.

Syafe'i, Rachmat. 2004. Fiqih Muamalah. Bandung: PT. Pustaka Setia. 